\title{
The effect of cement stabilization on the strength of the Bawen's siltstone
}

\author{
Edi Hartono ${ }^{1,3}$, Sri Prabandiyani Retno Wardani², and Agus Setyo Muntohar, \\ ${ }^{1}$ Ph.D Student, Department of Civil Engineering, Diponegoro University, Semarang, Indonesia \\ ${ }^{2}$ Department of Civil Engineering, Diponegoro University, Semarang, Indonesia \\ ${ }^{3}$ Department of Civil Engineering, Universitas Muhammadiyah Yogyakarta, Yogyakarta, Indonesia
}

\begin{abstract}
Siltstones are predominantly found along the Bawen toll-road. Siltstone is degradable soil due to weather session. The soil is susceptible to the drying and wetting and the changes in moisture content. Thus, Siltstone is problematic soils in its bearing capacity when served as a subgrade or subbase. The main objective of this study was to investigate the effect of cement stabilization on the strength of Siltstone. The primary laboratory test to evaluate the strength was Unconfined Compression Strength (UCS) and California Bearing Ratio (CBR). The cement content was varied from 2 to 12 per cent by weight of the dry soil. The soils were collected from the Ungaran - Bawen toll road. The specimens were tested after seven days of moist-curing in controlled temperature room of $25^{\circ} \mathrm{C}$. The CBR test was performed after soaking under water for four days to observe the swelling. The results show that the mudstones were less swelling after soaking. Cement-stabilized siltstone increased the CBR value and the UCS significantly. The addition of optimum cement content for siltstone stabilization was about 7 to 10 per cent.
\end{abstract}

\section{Introduction}

Rock lithology that includes claystone, siltstone, mudstone and shale is also known as mudrocks. The sedimentary rocks are found throughout the world [1]. This type of mudrock can be easily found along the Bawen toll road. The geology setting of the Bawen area was formed by Kerek and Kalibiuk Formation which is consisted of shale formation (see Fig. 1). Mudrock tends to weaken and soften when and contact with water. This behavior induces many problems of stability and settlement $[2,3]$. The rock is easy undergoes weathering if exposed and undergo repeated wetting and drying process even in just one cycle [4]. Muhroji and Wardani [5] reported that the typical mud rock, such as shale along the toll road has a high SPT value, but they generated instability of the roadway embankment.

In the process of road construction, it is often necessary to excavate and cut the slope. If the excavation is performed on the type of rock, it will affect the stability, either as a slope or a road body. Some cases of road settlement are caused by the lack of soil compaction and increasing the saturation [6]. Soil stabilization is needed to improve the integrity of the soil layer to extend the lifetime of the construction. Stabilization with cement or cement with

\footnotetext{
*Corresponding author: muntohar@umy.ac.id
} 
other materials, proven to be effective. Cement stabilization is mostly recommended for wellgraded aggregates with sufficient fine-grained fraction to fill the pores and bind coarsegrained aggregate [7].

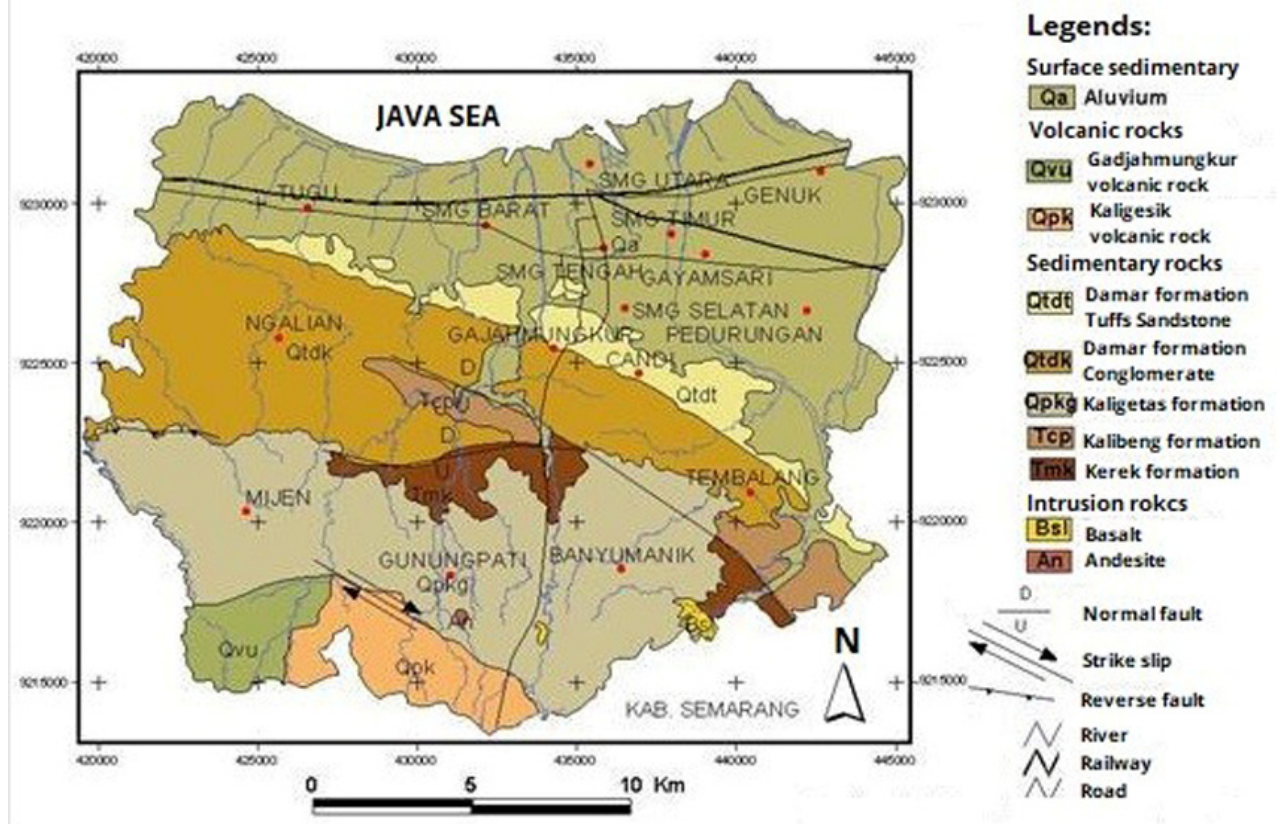

Fig. 1. Geology maps of the Semarang area, Thanden, et al. [8].

Many studies have been conducted on the cement stabilization of soft clay, low plasticity soil, and other problematic soil $[9,10]$. However, lessen research studies on the stabilization of mud rock type. In general, cement stabilization of mud rock type, such as siltstones, shales, improves the workability by reducing its plasticity index. Cement stabilization increases the optimum moisture content but decreases the maximum dry density [10]. Although the maximum dry density decreased, the strength increases significantly by mixing of cement. However, Lo and Wardani [11] found that the cement-stabilized silt exhibits a brittle behavior. Amount of cement that mixed with soil is one of the controlling factors to improve the properties of soil. Hartono et al. [12] present that the unconfined compressive strength of shale increases about four times by the addition of cement to about 8-9\%. For subgrade and subbase layer, Ilori [13] suggested 3\% and 10\% cement improve the unconfined compressive strength of marl and shale respectively. Furthermore, Mao et al. [14] explained that the resilient modulus of subgrade increases significantly with the increases in the amount of cement mixing in the soil.

Lessen study on the stabilization method of the mudrock type in Indonesia, hence a series of research is proposed to investigate the effectiveness of cement stabilization on mudrock type as subgrade. This paper presents the laboratory investigation of cement-stabilized siltstones for evaluating its index and mechanical properties, such as change of particle size, plasticity index, unconfined compressive strength and California Bearing Ratio. 


\section{Experimental method}

\subsection{Materials used}

\subsubsection{Soils}

One of the mudrocks type used in this study is siltstone which was taken from the slope side of the Bawen toll road. The typical siltstones sizes are shown in Fig. 2. After pulverizing, the soil consists of $51 \%$ of fines grain fraction; the rest is coarse grain fraction. Furthermore, the fragment is categorized as siltstones according to the criteria of Dick and Shakoor [15]. The plasticity index test indicates that the fines fraction is classified into low plasticity clay. Thus, the soil sample can be classified into A-6 group by AASHTO. Table 1 presents the properties of the sample used in this study.
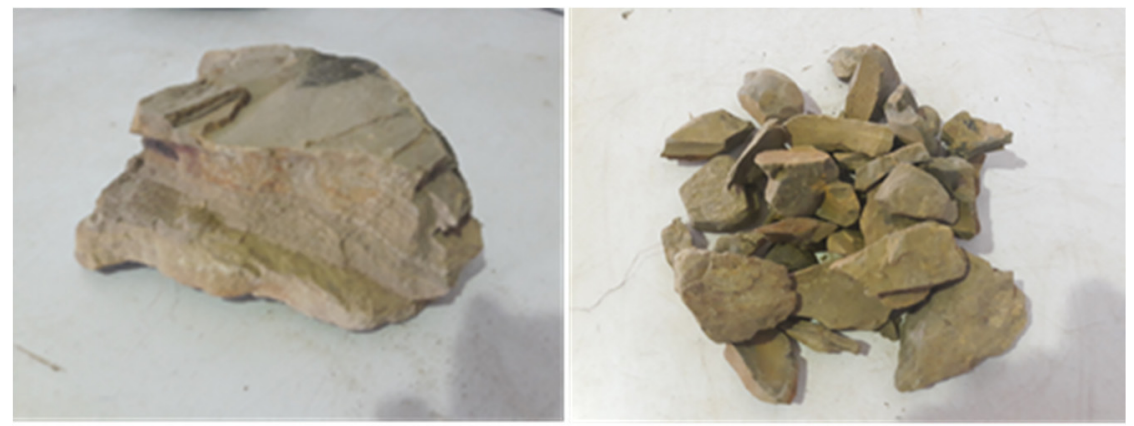

Fig. 2. The typical size of the siltstones collected from the site.

Table 1. The index properties of the soil samples.

\begin{tabular}{|l|l|l|l|}
\hline Parameter & Value & Parameter & Value \\
\hline Specific gravity, Gs & 2.58 & Soil fraction: & \\
\hline Liquid limit, LL (\%) & 38 & Clay size (\%) & 12.5 \\
\hline Plastic limit, PL (\%) & 22 & Silt size (\%) & 38.3 \\
\hline Plasticity index, PI (\%) & 16 & Sand (\%) & 49.2 \\
\hline Maximum dry density, MDD $\left(\mathrm{kN} / \mathrm{m}^{3}\right)$ & 14.8 & Optimum moisture content, OMC (\%) & 25 \\
\hline
\end{tabular}

\subsubsection{Cement}

The cement used was a general type of Portland cement (PC), having a specific gravity of 3.14. Its Blaine specific surface area was $3510 \mathrm{~m}^{2} / \mathrm{g}$. The PC contains of $63 \% \mathrm{CaO}, 20 \%$ $\mathrm{SiO}_{2}, 5.2 \% \mathrm{Al}_{2} \mathrm{O}_{3}, 3.3 \% \mathrm{Fe}_{2} \mathrm{O}_{3}, 2.4 \% \mathrm{SO}$, and $2.5 \%$ loss of ignition (LOI). The density of cement was about $2950 \mathrm{~kg} / \mathrm{m}^{3}$. The PC confirmed to Type I according to the ASTM C150 [16].

\subsection{Specimen preparation and testing procedures}

A series of laboratory investigation were conducted including index properties (Atterberg limits, particle size distribution), compaction, and unconfined compressive strength, and California Bearing Ratio tests. The soil was mixed with various cement content from $2 \%$ to $12 \%$. The testing design of this experiment is presented in Table 2 . The specimens were prepared according to ASTM D4609 [17] which recommended the tests after seven days of curing at high humidity. Since the strength of soil is affected by the initial water content, then 
the UCS and CBR specimens were mixed at the same moisture content of the OMC of unstabilized soil. The liquid limit, plastic limit, and plasticity index were tested according to the ASTM D4318 [18]. The particle size distribution of the stabilized soils was performed as stated in ASTM D422 [19].

The unconfined compressive strength was tested by ASTM D2166 [20]. The specimen was prepared with a diameter of $50 \mathrm{~mm}$ and a height of $100 \mathrm{~mm}$. The soil-cement slurry was compacted before the initial time setting of cement paste or 60 minutes [16]. The soil mixture was compacted statically in the splitting-cylindrical mold. After compaction, the specimen was extruded and cured for seven days at high humidity room. Hereafter, the specimen was loaded to reach a failure to obtain unconfined compressive strength.

Table 2. Laboratory testing design.

\begin{tabular}{|l|l|c|c|c|c|}
\hline \multirow{2}{*}{ Specimens } & \multirow{2}{*}{ Code } & \multicolumn{5}{c|}{ Test Type } \\
\cline { 3 - 6 } & & Att. & PSD & UCS & CBR \\
\hline Soil & S & $\bullet$ & $\bullet$ & $\bullet \bullet \bullet$ & $\bullet \bullet$ \\
\hline Soil + 2\% PC & SC2 & $\bullet$ & $\bullet$ & $\bullet \bullet \bullet$ & $\bullet \bullet$ \\
\hline Soil + 5\% PC & SC5 & $\bullet$ & $\bullet$ & $\bullet \bullet \bullet$ & $\bullet \bullet$ \\
\hline Soil + 7\% PC & SC7 & $\bullet$ & $\bullet$ & $\bullet \bullet \bullet$ & $\bullet \bullet$ \\
\hline Soil + 10\% PC & SC10 & $\bullet$ & $\bullet$ & $\bullet \bullet \bullet$ & $\bullet \bullet$ \\
\hline Soil + 12\% PC & SC12 & $\bullet$ & $\bullet$ & $\bullet \bullet \bullet$ & $\bullet \bullet$ \\
\hline $\begin{array}{l}\text { Notes: Att. = Atterberg limits; PSD = particle size distribution; UCS = unconfined } \\
\text { compressive strength; CBR = California bearing ratio; } \bullet \text { number of specimen }\end{array}$
\end{tabular}

Soaked CBR test was done using ASTM D1883 [21]. The CBR test specimens were 151 $\mathrm{mm}$ in diameter and a height of $178 \mathrm{~mm}$. The soil-cement slurry was compacted in the cylindric mold in three layers. Each layer was compacted using 56 blows per layer. Two specimens were prepared or each soil-cement mixture. The specimens were cured for seven days at high humidity room. After curing, the specimens were subjected to soaking for four days to measure the swelling under $4.5 \mathrm{~kg}$ surcharge. Hereafter, a bearing test was applied at a penetration rate of about $1.27 \mathrm{~mm} / \mathrm{min}$.

\section{Results and discussion}

\subsection{Index properties}

The consistency limits of cement-stabilized soil are presented in Fig. 3. It has been shown that the plasticity index decreases as the cement content increases. The reducing of plasticity index as the result of the decreases in liquid limit and increases in the plastic limit. The figure is alluding to conclude that cement increases the plastic limit considerably. The consistency limits change significantly by adding the cement up to $5 \%$. Furthermore, the change of plasticity relates to the change in particle size distribution as shown in Fig. 4. Fig. 4 illustrates that cement alters the particle size distribution of soil. The fine-grained fraction change to be a coarser grain. The characteristic indicates that agglomeration takes places in the cementmodified soil.

\subsection{Unconfined compressive strength}

Fig. 5a shows the effect of cement content on the unconfined compressive strength of soil. The figure indicates that the UCS increases almost linearly with the increasing of cement. The UCS increases from $34 \mathrm{kPa}$ to $849 \mathrm{kPa}$ by the addition of $12 \%$ cement. Based on the Indonesian Standard for cement-treated base [22], the minimum UCS for base course layer 
is $600 \mathrm{kPa}$. Thus, this study recommends that the addition of $7 \%$ cement be suitable to improve he siltstone as base course layer. This result is consistent with Ilori [13].

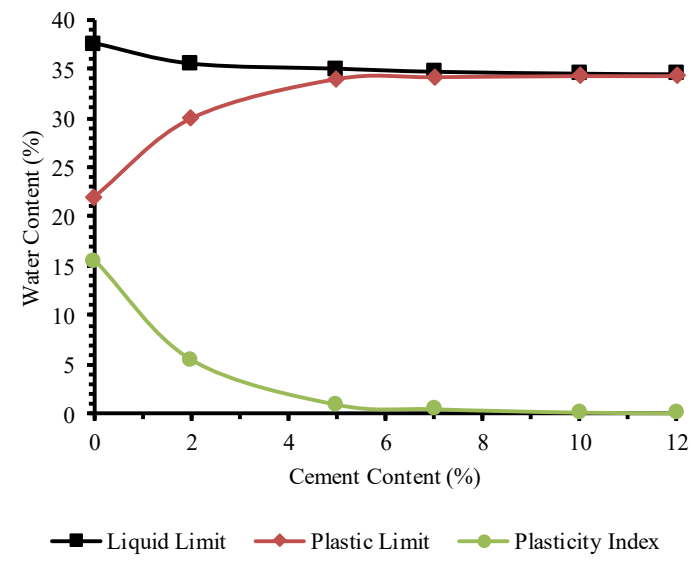

Fig. 3. The variation of consistency limits of the soil-cement mixtures.

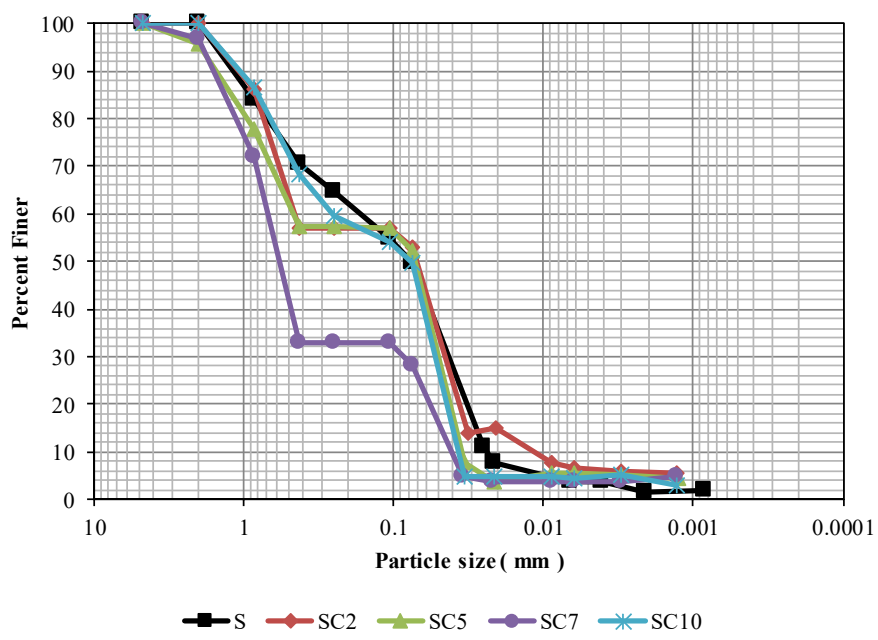

Fig. 4. Particle size distribution of the soil-cement mixtures.

\subsection{California bearing ratio}

Fig. $5 \mathrm{~b}$ presents the relationship between CBR and the cement content in the soil-cement mixtures. The figure shows that the CBR increases almost linearly with the increases in cement content up to $10 \%$. Hereafter, the CBR tends to decrease after addition of $10 \%$ cement. The CBR increases significantly from $2.54 \%$ to $59 \%$ by the addition of $10 \%$ of cement. CBR is commonly used as the requirement for subgrade design of road pavement. The Indonesian Standard [23] for cement-modified soil requires a CBR value of $4-7 \%$ for subgrade and $20 \%$ for base-course. According to the standard, this study recommends $2 \%$ cement to modify subgrade and base-course. 


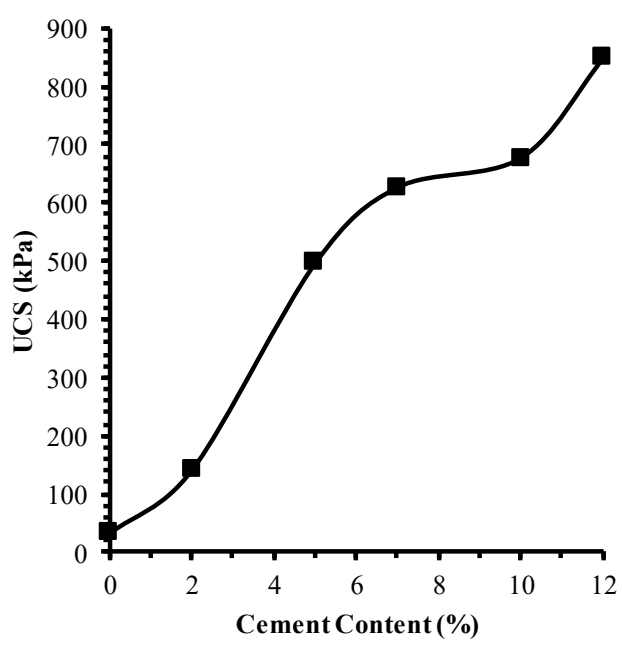

(a)

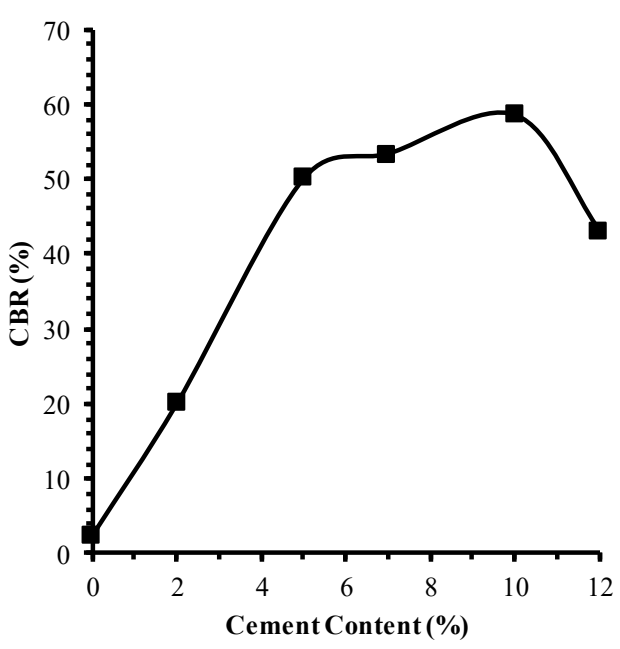

(b)

Fig. 5. Effect of cement content on the variation of (a) UCS, (b) CBR.

\subsection{Discussion}

The results in Fig. 3, it appears that if the cement content increases the liquid limit decreases and the plastic limit increases so the plasticity index decreases. The results mean that the stabilization of cement on siltstone is quite useful in reducing the soil plasticity. Decreasing in plasticity index is an indicator of stabilization [17]. Principally, the consistency limit relates to the affinity of clay to water. Reduction in affinities of clay soil for moisture content can be attributed to three mechanisms: (a) destruction of clay-mineral structures in reaction with cement, (b) cementation of fine mineral particles into aggregates, and (c) modification and masking of the surface, and support of restraint of particles by cementitious reaction products [8].

Increasing in UCS and CBR can be attributed to the reaction product in the soil-cement mixture. Wardani and Muntohar (2018) explain that in the cement-stabilized soil will produce the main products of tricalcium silicate and secondary products of calcium silicate hydrate and calcium aluminate hydrate. The main products harden into high strength additives. The secondary process increases the strength and durability of soil-cement by producing an additional cementation agent to increase the bonding strength between the particles. Several other parameters may control the increase of the UCS such as dry density, water content, and water to cement ratio [24].

In this research, there was no swelling observed for four days soaking of unstabilized soil. It is because of no-swelling clay mineral in the soil origin. During soaking, the specimen absorbs water and result in increases in moisture content. Then, this mechanism reduces the CBR value of the cement-stabilized soil. However, Bhattacharja and Bhatty [9] explained that increase in soaked CBR values might be attributed to a renewed hydration of the core of the relatively larger cement grains.

\subsection{Conclusion}

The research has been successfully conducted to evaluate the effectiveness of cement for the siltstone stabilization. The experiments show that the use of cement improves the geotechnical engineering of the siltstones significantly. Addition of cement up to $5 \%$ 
decreases the plasticity index of soil significantly. For stabilization, 7\% cement addition is suitable to alter the soil particle size and fulfil the requirement for subgrade and base-course layer of the paved road according to Indonesian Standard [22, 23]. This study found that the UCS and CBR value of stabilized-soil increases about four times by addition of $7 \%$ cement.

\section{References}

1. H. Nahazanan, S. C. Afshin, A.Z.M. Yusoff, B.K. Huat, Eng. Geol., 158, 48-56 (2013)

2. N. Yoshida, K. Hosikawa, J. Geotech. Geoenviron. Eng., 130(5), 519-525 (2004)

3. K. Sharma, T. Kiyota, H. Kyokawa, Influence of cyclic wetting and drying on stress and deformation characteristics of crushed mudstones in direct shear test, The $5^{\text {th }}$ TaiwanJapan Joint Workshop on Geotechnical Hazards from Large Earthquakes and Heavy Rainfalls, 12-15 November 2012, Tainan, Taiwan (2012)

4. K. Sharma, T. Kiyota, H. Kyokawa, Effect of Slaking on the Engineering Behaviour of the Crushed Mudstone, Institute of Industrial Science, University of Tokyo, Bulletin of ERS, No. 46, (2013)

5. Muhrozi, S. P. R. Wardani, Problem of High Embankment on Clay Shale at SemarangUngaran Toll Road STA. $5+500$ to $6+300$, Proceedings of the 3rd International Conference Geotechnical Engineering for Disaster Mitigation and Rehabilitation and 5th International Conference Highway Engineering 2011 Semarang, Indonesia, 18 - 20 May 2011, 159-171, (2011)

6. B.C. Hale, C.W. Lovell, L.E. Wood, Transport. Res. Rec. 790, 45-52 (1981)

7. S.P.R. Wardani, Muntohar, A.S, Perbaikan Tanah, LP3M UMY, (2018)

8. R.E. Thanden, H. Sumadiredja, P.W. Richards, K. Sutisna, and T.C. Amin, Peta Geologi Lembar Magelang dan Semarang, Jawa, skala 1:100.000. P3GL, Bandung, (1996)

9. S. Bhattacharja, J.I. Bhatty, Comparative Performance of Portland Cement and Lime in Stabilization of Moderate to High Plasticity Clay Soils, RD125, Portland Cement Association, Skokie, Illinois, USA, (2003).

10. F. Sariosseiri, B, Muhunthan, Eng. Geol., 104, 119-125, (2009)

11. S.R. Lo, S.P.R. Wardani, Canadian Geotech. J., 39, 77-89, (2002)

12. E. Hartono; S.P.R. Wardani, Muntohar, A.S., Pengaruh Campuran Semen Pada Tanah Shale Bawen Terhadap Rasio Disintegritas (DR) dan Kuat Tekan Bebas, The $21^{\text {st }}$ Annual National Conference on Geotechnical Engineering, Jakarta, 7-8 November 2017, 53-58, (2017)

13. A.O. Ilori, Springer Plus, 5(209), 1-13, (2016)

14. X. Mao, C.J. Miller, L. Liu, J. Traffic Transport. Eng., 4(4), 403-411, (2017)

15. J.C. Dick, A. Shakoor, Eng. Geol., 25, 31- 46, (1992)

16. ASTM C150/C150M-17, Standard Specification for Portland Cement, ASTM International, West Conshohocken, PA, (2017)

17. ASTM D4609-08, Standard Guide for Evaluating Effectiveness of Admixtures for Soil Stabilization, ASTM International, West Conshohocken, PA, (2008)

18. ASTM D4318-17, Standard Test Methods for Liquid Limit, Plastic Limit, and Plasticity Index of Soils, ASTM International, West Conshohocken, PA, (2017)

19. ASTM D422-63, Standard Test Method for Particle-Size Analysis of Soils, ASTM International, West Conshohocken, PA, (2007) 
20. ASTM D2166-17, Standard Test Method for Unconfined Compressive Strength of Cohesive Soil, ASTM International, West Conshohocken, PA, (2017)

21. ASTM D1883-07, Standard Test Method for CBR (California Bearing Ratio) of Laboratory-Compacted Soils, ASTM International, West Conshohocken, PA, (2007)

22. SNI 03-3438, Tata Cara Pelaksanaan Stabilisasi Tanah Dengan Semen Portland Untuk Jalan, Badan Standarisaisi Nasional, Jakarta, (1994)

23. Bina Marga, Manual Perkerasan Jalan Nomor 02/M/BM/2013, Kementerian Pekerjaan Umum, Jakarta, (2013)

24. N.S. Ikhlef, M.S. Ghembaza, M. Dadouch, Geotech. Geol. Eng. 33, 1067-1079, (2015) 